\title{
JUURNAL.RU
}

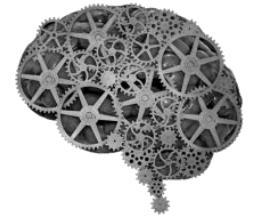

COMPANY GROUP "INTELLEKT"

\author{
Янукян А.А. \\ Кубанский государственный технологический университет \\ Краснодар, Россия
}

doi: 10.18411/lj2016-6-5-11

\section{Создание узловых координационно-логистических центров при международных перевозках грузов}

В статье раскрывается понятие координационно-логистического центра, рассматриваются его основные функции. Исследуется их роль в развитии экономики и определяются положительные эффекты создания координационнологистических центров.

Текущие процессы глобализации на мировом транспортно-логистическом рынке, усиливающаяся экономическая взаимозависимость стран мира,произошедшие интеграционные процессы требуют от российских логистических компаний широкого использования современных технологий и инновационных схем в работе для повышения конкурентоспособности компании и дальнейшего развития логистической инфраструктуры. Для этого необходимо обширное введение логистических технологий. Только путем создания координационно-логистических центров (КЛЦ) транспортных узлов они могут быть выполнены из реализации комплексных транспортных и логистических технологий посредством экономических и регуляторных механизмов [1].

Необходимость формирования в крупных узлах отечественной транспортной инфраструктуры логистических центров, опирающихся в своей работе на единую нормативно-правовую базу и современные информационные 
технологии, обозначена в Транспортной стратегии Российской Федерации на период до 2030 г.

Европейская экономическая комиссия $\mathrm{OOH}$ в своем документе «Терминология комбинированных перевозок» закрепила следующее определение логистического центра: логистический центр(logisticcentre) - это территориальное объединение независимых компаний и органов, занимающихся грузовыми перевозками (например, транспортных посредников, грузоотправителей, операторов перевозок) и сопутствующими услугами (например, по хранению, техническому обслуживанию и ремонту), включающее, по меньшей мере, один терминал.

В данном определении подчеркивается основная идея координационнологистического центра - компактная группировка складов и других объектов логистической инфраструктуры вокруг мультимодального терминала.

В США, Японии, Китае наиболее часто используют терминLogisticCentre логистический центр. Во англоязычных странах чаще используется термин или FreightVillage - грузовая деревня, илиTerminalVillage - терминальная деревня, в Германии и Австрии употребляют термин GuterVerkehrZentrum - грузовой транспортный центр. В Италии же применяют термин Interporto - перевалочный пункт.

В России координационно-логистическими центрами часто называют просто крупные складские комплексы. Иногда встречается применение понятия КЛЦ к транспортному узлу или к населенному пункту, где размещены различные склады, не связанные между собой,имеется морской порт и железнодорожная станция.

КЛЦ с каждым годом играют все более значимую роль в экономике развитых стран, определяя во многом развитие их товаропроводящих систем. Логистические центры обеспечивают тесное взаимодействие грузоотправителей, экспедиторов, таможенных структур, поставщиков дополнительных услуг с магистральной транспортной системой, концентрацию и оптимальное 
направление транспортных потоков, стыковку международных и национальных транспортных коридоров, эффективное взаимодействие различных видов транспорта.

Для наилучшей реализации своих функций КЛЦ размещаются в узловых пунктах международных транспортных коридоров, в крупных контейнерных портах, в индустриальных районах и в свободных экономических зонах. Часто КЛЦ создают вблизи крупных городов, что сокращает нагрузку на УДС города, создаваемую большегрузными автомобилями, и позволяет освободить городскую территорию от складов,грузовых железнодорожных станций и других подобных объектов.

Один мультимодальныйлогистический центр играет большую роль в своём экономическом районе. Однако же для качественной и эффективной работы с международными транзитными грузами необходимо, чтобы аналогичные центры создавались в других транспортных центрах, с которыми данный центр имеет транспортные связи. Недостаточно эффективной и качественной, проведенной в соответствии с международными требованиями переработки и транспортировки груза только лишь в зоне влияния данного КЛЦ. Необходимо, чтобы такой уровень скорости и качества переработки груза был обеспечен на всем протяжении перевозки груза и за пределами влияния этого логистического центра.

Создание мультимодальных КЛЦ позволяет сохранить интеграцию товаропотоков и эффект масштаба транспортировки в глобальных цепях поставок. Потоки товаров, которые бы распылялись в морских портах в противном случае, направляются контейнерными поездами в координационнологистические центры, где в наличии есть достаточные мощности для их переработки и хранения. Таким образом достигается так называемое «сухопутное продление» коммуникаций глобальной морской контейнерной системы с сохранением ее главных особенностей - эффективной технологии и низкозатратных магистральных перевозок. 
Использование координационно-логистических центров позволяет странам эффективно внедрятся в международную систему цепей поставок. В некоторых странах с низким уровнем развития железных дорог создаются КЛЦ, которые обслуживаются, в основном, автотранспортными терминалами. Но и в этом случае прямой доступ к регулярному транспортному сервису даст компаниям, размещенным на территории «терминальной деревни», преимущество перед другими субъектами рынка.

В целом, создание координационно-логистических центров создает предпосылки для роста выпуска продукции в районах, где будет сосредоточена транспортная инфраструктура, будет способствовать диверсификации экономики региона и создаст основу для развития ее конкурентоспособной и инновационной промышленности, а также ускорит процесс адаптации к новым экономическим условиям [2].

\section{Литература:}

1. Кузьмина М.А., Надирян С.Л., Чернобривец Е.О. Основные концепции развития технологий мультимодальных перевозок // Электронный политематический журнал «Научные труды КубГТУ». - 2015. - №6.

2. Бекетова О. Ю., Пилипович Е. Д. СОЗДАНИЕ МУЛЬТИМОДАЛЬНЫХ ЛОГИСТИЧЕСКИХ ЦЕНТРОВ: ПЕРСПЕКТИВЫ РАЗВИТИЯ В ЦЕНТРАЛЬНОЙ АЗИИ // Научное сообщество студентов ХХІ столетия. ЭКОНОМИЧЕСКИЕ НАУКИ: сб. ст. по мат. ХХXIII междунар. студ. науч.-практ. конф. № 6(33). URL: http://sibac.info/archive/economy/6(33).pdf (дата обращения: 16.05.2016)

3. Международные перевозки: учебник для студ. учреждений высш. проф. образования / В.М. Курганов, Л.Б. Миротин; под ред. Л.Б. Миротина. - 2-е изд., стер. - М.: Издательский центр «Академия», 2013. - 304 с. 